\title{
Un Muppet perdido en el mediastino
}

\section{A Muppet Lost in the Mediastine}

\author{
Santiago Miraglia ${ }^{1}$ Emiliano Mayor ${ }^{1}$ \\ ${ }^{1}$ Hospital Interzonal General de Agudos General José de San Martín, \\ Av. 1 1794, La Plata, Buenos Aires, Argentina
}

Rev Argent Radiol 2022;85(Suppl S1):S20.

La doble vena cava superior ( $\mathbf{- F i g . 1}$ ) es una anormalidad sumamente rara (con una incidencia del $0,3 \%$ ), pero es la más frecuente dentro de las malformaciones de las venas torácicas y se da por variaciones en el desarrollo embriológico torácico venoso.

En la mayoría de los casos, los pacientes son asintomáticos y es un hallazgo incidental, visualizado por imágenes realizadas por otras razones.

Es importante tener en cuenta esa variante como diagnóstico diferencial de ensanchamiento mediastinal o ante cualquier complicación que se pueda dar ante la colocación de un catéter venoso central o marcapasos.

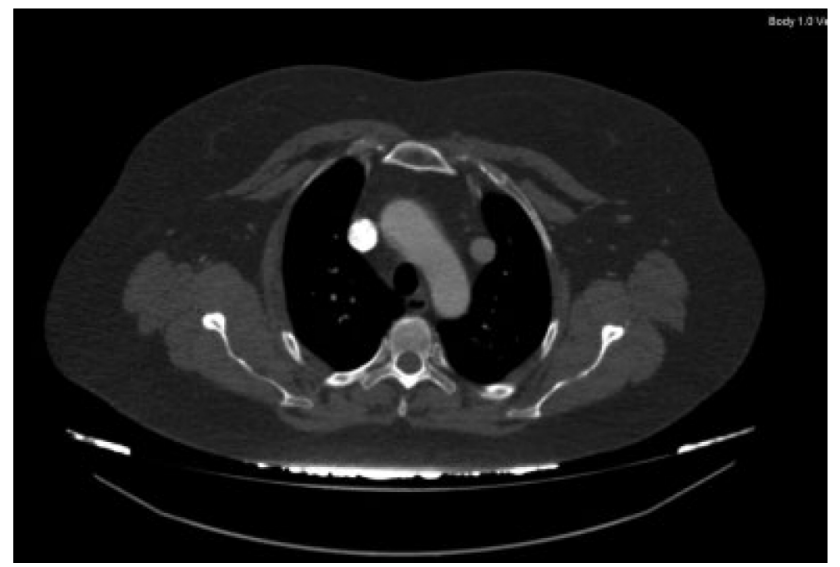

Figura 1 TC de tórax con contraste endovenoso, corte axial y ventana para mediastino: a nivel del cayado aórtico, se observa doble vena cava superior.

received

January 21, 2020

accepted

February 7, 2020

published online

April 22, 2020
Address for correspondence Santiago Miraglia, Calle 50 1533, La Plata, Buenos Aires, Argentina (e-mail: santi_miraglia@hotmail.com).

Presentamos el caso de un paciente al que se le realizó una tomografía computada (TC) de tórax con contraste endovenoso en control por un nódulo pulmonar. Incidentalmente, en un corte axial con ventana para mediastino se puede visualizar la duplicación de la vena cava superior a cada lado del cayado aórtico, configurando, en ese caso, la imagen de la cara del querido personaje Gonzo, de los Muppets (-Fig. 2).

\section{Agradecimientos}

Los autores agradecen a la Dra. María Paula Seguí.

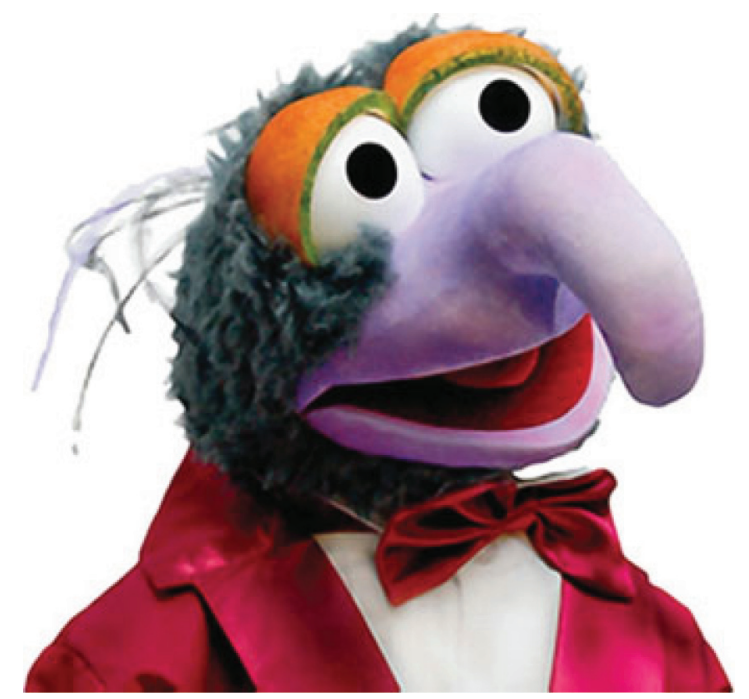

Figura 2 Imagen del querido y excéntrico Gonzo, de los Muppets.

(c) 2020. Asociación Civil Sociedad Argentina de Radiología and Federacion Argentina de Asociaciones de Radiología, Diagnóstico por Imágenes y Terapia Radiante. All rights reserved.

This is an open access article published by Thieme under the terms of the Creative Commons Attribution-NonDerivative-NonCommercial-License, permitting copying and reproduction so long as the original work is given appropriate credit. Contents may not be used for commercial purposes, or adapted, remixed, transformed or built upon. (https://creativecommons.org/ licenses/by-nc-nd/4.0/)

Thieme Revinter Publicações Ltda., Rua do Matoso 170, Rio de Janeiro, RJ, CEP 20270-135, Brazil 